Article

\title{
When Activator and Inhibitor of PPAR $\alpha$ Do the Same: Consequence for Differentiation of Human Intestinal Cells
}

\author{
Katerina Cizkova, Tereza Foltynkova, Jiri Hanyk, Zbynek Kamencak and Zdenek Tauber *
}

Citation: Cizkova, K.; Foltynkova, T.; Hanyk, J.; Kamencak, Z.; Tauber, Z. When Activator and Inhibitor of PPAR $\alpha$ Do the Same: Consequence for Differentiation of Human Intestinal Cells. Biomedicines 2021, 9 , 1255. https://doi.org/10.3390/ biomedicines 9091255

Academic Editor: Cimini Annamaria

Received: 5 August 2021

Accepted: 13 September 2021

Published: 17 September 2021

Publisher's Note: MDPI stays neutral with regard to jurisdictional claims in published maps and institutional affiliations.

Copyright: (c) 2021 by the authors. Licensee MDPI, Basel, Switzerland. This article is an open access article distributed under the terms and conditions of the Creative Commons Attribution (CC BY) license (https:/ / creativecommons.org/licenses/by/ $4.0 /)$.
Department of Histology and Embryology, Faculty of Medicine and Dentistry, Palacky University, 77900 Olomouc, Czech Republic; katerina.cizkova@upol.cz (C.K.); tereza.foltynkova@upol.cz (F.T.); jiri.hanyk01@upol.cz (H.J.); zbynek.kamencak01@upol.cz (K.Z.)

* Correspondence: zdenek.tauber@upol.cz; Tel.: +420-585-632-283; Fax: +420-585-632-966

\begin{abstract}
Peroxisome proliferator-activated receptor $\alpha(\operatorname{PPAR} \alpha)$ is a ligand-dependent transcription factor that plays a role in various processes including differentiation of several cell types. We investigated the role of PPAR $\alpha$ in the differentiation of intestinal cells using HT-29 and Caco2 cell lines as a model as well as human normal colon and colorectal carcinoma tissues. We detected a significant increase in PPAR $\alpha$ expression in differentiated HT-29 cells as well as in normal surface colon epithelium where differentiated cells are localised. Thus, it seems that PPAR $\alpha$ may play a role in differentiation of intestinal cells. Interestingly, we found that both PPAR $\alpha$ activators (fenofibrate and WY-14643) as well as its inhibitor (GW6471) regulated proliferation and differentiation of HT-29 cells in vitro in the same way. Both compounds led to a decrease in proliferation accompanied by a significant increase in expression of villin, intestinal alkaline phosphatase (differentiation markers). Moreover, the same trend in villin expression was observed in Caco2 cells. Furthermore, villin expression was independent of subcellular localisation of PPAR $\alpha$. In addition, we found similar levels of PPAR $\alpha$ expression in colorectal carcinomas in comparison to adjacent normal epithelium. All these findings support the hypothesis that differentiation of intestinal epithelium is PPAR $\alpha$-independent.
\end{abstract}

Keywords: cell proliferation; cell differentiation; colorectal carcinoma; peroxisome-proliferator activated receptor

\section{Introduction}

Peroxisome proliferator-activated receptor $\alpha(\operatorname{PAAR} \alpha)$ is a ligand-dependent transcription factor that belongs to the nuclear receptor superfamily. PPAR $\alpha$ is activated by a wide range of both endogenous and exogenous ligands such as dietary fatty acids, eicosanoids, hypolipidaemic drugs, phthalates and pesticides [1,2]. After ligand binding, PPARs heterodimerise with retinoid $X$ receptor, bind to peroxisome proliferator response elements (PPREs) and regulate the expression of a number of target genes [3]. PPAR $\alpha$ regulates various cellular function including energy metabolism, oxidative stress, immune response, xenobiotic metabolism, cell proliferation, differentiation and carcinogenesis [1-5].

PPAR $\alpha$ is molecular target of fibrates. Fibrates, such as fenofibrate, bezafibrate, clofibrate and gemfibrozil, are widely used drugs that reduce serum lipids, and they are the first choice for hypertriglyceridemia when a change in diet is not sufficient. These compounds are generally well-tolerated drugs with good safety profiles [6-8]. Other synthetic compounds that activate PPAR $\alpha$, such as WY-14643 (or pyrinixic acid), are not approved for clinical use. However, they are often used for research purposes [6]. Based on mouse models of human diseases, fenofibrate protects the intestine from colitis-induced permeability [9], and it could also have a possible therapeutic potential in Crohn's disease [10]. Although there are studies suggesting that synthetic PPAR $\alpha$ ligands could be useful for prevention and treatment of different cancers [3,11-16], there are also studies which have described an increase in cell proliferation after fibrates treatment [17-19]. Thus, further investigation of their potential use in cancer treatment is needed. 
The activation of PPAR $\alpha$ plays a role in the differentiation of various cell types. It is necessary for the differentiation of murine embryonic stem cells into cardiomyocytes in vitro [20]. It also leads to the promotion of adipocyte differentiation [21] as well as of angiogenic progenitor cell differentiation toward endothelial lineage [22]. It is known that activation of PPAR $\alpha$ enhances cardiac progenitor differentiation [23]. Moreover, PPAR $\alpha$ regulates myeloid lineage differentiation, but it negatively modulates the differentiation of bone marrow-derived progenitor cells [24]. In addition, activation of PPAR $\alpha$ promotes osteogenic differentiation of MC3T3-E1 cells [25] and PPAR $\alpha$ stimulates keratinocyte differentiation in mice and human skin explants [26].

Intestinal epithelium regenerates intensively during life. The undifferentiated cells are localised in the crypt area; during differentiation into absorptive and secretory cells, they migrate upward and are shed out at the villous tips [27]. Although PPAR $\alpha$ is expressed in intestines very early in prenatal development, its role in intestinal cell differentiation is unknown. Previous studies have shown detection of PPAR $\alpha$ expression in human intestines during prenatal development at mRNA [1] as well as protein levels [28,29]. PPAR $\alpha$ mRNA level has been increased with gestational age in foetuses from 8 to 18 weeks of age [1]. PPAR $\alpha$ has been weak in jejunum at 7 and 12 weeks and not detected at 16 weeks, while the expression in the ileum was moderate at 12 and 16 weeks and increased at 22 weeks. PPAR $\alpha$ has been detected in colon at 8 weeks, but it has been decreased at 14 and 20 weeks [28]. The expression of PPAR $\alpha$ also differs along the crypt-villous axis. Until the 11th week of prenatal development, expression has been stronger in the area of future crypts than in apical parts of villi. After this period, the expression along crypt-villous axis has been comparable [29]. PPAR $\alpha$ is also expressed in postnatal life. In murine small intestine, the expression of PPAR $\alpha$ has shown to increase according to the crypt-villous axis [30]. In humans, PPAR $\alpha$ mRNA has been detected in normal colon tissue [31], although only a low expression of PPAR $\alpha$ has been detected at the protein level by immunohistochemistry [4]. Moreover, in vitro differentiation of Caco2 cells in long-term culture was accompanied with an increase in PPAR $\alpha$ expression [32].

The aim of this study was to investigate the possible role of PPAR $\alpha$ in cell differentiation using HT-29 and Caco2 cells as a model. Under standard culture conditions, these cells do not differentiate, but they can be differentiated in vitro after sodium butyrate treatment (HT-29) or spontaneously in post-confluence culture conditions (Caco2) and then resemble human colon epithelium [33,34]. We examined the effect of PPAR $\alpha$ activators fenofibrate and WY-14643 and PPAR $\alpha$ inhibitor GW6471 on cell proliferation activity and expression of villin and intestinal alkaline phosphatase (as the markers of intestinal cell differentiation) as well as PPAR $\alpha$ expression itself. Moreover, as carcinogenesis could be seen as result of the disruption of the normal differentiation process, the PPAR $\alpha$ expression pattern in colorectal carcinoma and healthy margin tissues samples was also explored.

\section{Material and Methods}

\subsection{Cell Culture and Treatment}

Human colorectal tumour-derived cell lines HT-29 and Caco2 were obtained from American Type Culture Collection. The cell lines' authentication via STR profiles was performed by the Department of Clinical Genetics, Palacky University, Olomouc. The cells were routinely cultured in DMEM (Sigma-Aldrich, St. Louis, USA, cat. no. D6171) supplemented with 10\% (HT-29) and 15\% (Caco2) FBS (HyClone, Marlborough, USA, cat. no. SV30160.03), penicillin $(100 \mathrm{U} / \mathrm{mL})$, and streptomycin $(100 \mathrm{mg} / \mathrm{L})$. Cells were incubated at $37^{\circ} \mathrm{C}$ and $5 \% \mathrm{CO}_{2}$ and passaged twice per week.

The whole experimental procedure is summarised in Supplementary Materials Figure S1. Undifferentiated cells from both cell lines were seeded and adhered overnight. The seeding density was dependent on the assay. For the proliferation assay and In-Cell ELISA, the cells were seeded in 96-well cultivation plates (TPP, cat. no. 92696) at a density of 10,000 cells/well (HT-29) and 7000 cells/well (Caco2). For immunocytochemistry and multiplex immunofluorescent staining, the HT-29 cells were seeded in 8-well cell culture 
slides (SPL Life Sciences, Naechon-Myeon, Korea, cat. no. 30108) at a density off 18,000 cells/well.

The next day after seeding, the cells were treated with PPAR $\alpha$ activators (fenofibrate (Cayman Chemicals, Michigan, USA cat. no. 10005368) or WY-14643 (Sigma-Aldrich, St. Louis, USA, cat. no. C7081) and PPAR $\alpha$ inhibitor (GW6471 (Cayman Chemicals, Michigan, USA, cat. no. 11697)) in the following concentrations: $25 \mu \mathrm{M}$ and $150 \mu \mathrm{M}$ (HT-29) or 200 $\mu \mathrm{M}$ (Caco2) fenofibrate, $25 \mu \mathrm{M}$ and $200 \mu \mathrm{M}$ WY-14643, and $1 \mu \mathrm{M}$ and $10 \mu \mathrm{M}$ GW6471. The undifferentiated control cells were treated with an appropriate concentration of DMSO. Then, the cells treated with PPAR $\alpha$ ligands (or DMSO) were incubated for $72 \mathrm{~h}$ at $37^{\circ} \mathrm{C}$.

For obtaining differentiated cells, HT-29 cells were seeded, incubated overnight, and then treated with $5 \mathrm{mM}$ sodium butyrate (NaBt; Sigma-Aldrich, St. Louis, USA, cat. no. B5887) for $72 \mathrm{~h}$. For obtaining differentiated Caco2 cells, the cells were cultured for 14 days after reaching confluence. The growth medium was changed twice per week. After the differentiation process, the medium was changed and the cells were treated with PPAR $\alpha$ ligands for $72 \mathrm{~h}$, as mentioned above. The differentiated cells used as controls were treated by appropriate concentration of DMSO. The cells were not reseeded during the experiments.

\subsection{Proliferation Assay}

The effect of used concentrations of fenofibrate, WY-14643, and GW6471 on cell proliferation in both undifferentiated and differentiated cells was measured by the WST-1 proliferation test (Roche, cat. no. 11644807001) carried out according to the vendor's protocol. After the incubation period with tested PPAR $\alpha$ activators and inhibitor, WST-1 reagent was added and incubated for $60 \mathrm{~min},\left(37^{\circ} \mathrm{C}, 5 \% \mathrm{CO}_{2}\right)$. Then, the absorbance was measured by the microplate reader Power Wave XS (Bio-Tek, Winnoski, USA) at $450 \mathrm{~nm}$. The WST-1 test was performed in three independent triplicates $(n=9)$.

\subsection{In-Cell ELISA (ICE)}

The changes in protein expression of known markers of intestinal differentiation, villin and intestinal alkaline phosphatase (IAP) as well as PPAR $\alpha$, itself, were investigated by the In-Cell ELISA colorimetric kit (ThermoScientific, Waltham, USA, cat. no. \#62200). After the incubation period, the cells were washed with PBS and fixed with $4 \%$ paraformaldehyde for $10 \mathrm{~min}$ at RT. The procedure was performed according to the vendor's protocol. The following rabbit polyclonal primary antibodies were used: villin (GeneTex, Hsinchu, Taiwan; cat. no. GTX110034) at a dilution of 1:1500; IAP (GeneTex, Hsinchu, Taiwan, cat. no. GTX112100) at a dilution of 1:500; PPAR $\alpha$ (GeneTex, Hsinchu, Taiwan, cat. no. GTX28934) at a dilution of 1:1000. The antibody signals (measured as absorbance at $450 \mathrm{~nm}$ ) were normalised to Janus green staining intensity (a mitochondrial dye; measured as absorbance at $615 \mathrm{~nm}$ ) to account for cell number variation. The results are shown as relative expression (\%) in comparison to appropriate control cells (100\%). The absorbance was measured by microplate reader Power Wave XS (Bio-Tek, Winnoski, USA). The experiment was performed in three independent duplicates $(n=6)$.

\subsection{Immunocytochemistry}

The HT-29 cells were seeded in 8-well cell culture slides treated with $150 \mu \mathrm{M}$ fenofibrate, $200 \mu \mathrm{M}$ WY-14643, and $10 \mu \mathrm{M}$ GW6471 as mentioned above and then fixed with $4 \%$ paraformaldehyde for $15 \mathrm{~min}$. Before immunostaining, the cells were hydrated, permeabilised with $0.1 \%$ Triton- $X$ for $15 \mathrm{~min}$, and heat-induced antigen retrieval in citric buffer pH6 $\left(120^{\circ} \mathrm{C}, 15 \mathrm{~min}\right.$, Histos device) was performed. After that, the endogenous peroxidase activity was blocked by PolyDetector Peroxidase Blocker (Bio SB, part of the detection kit) for $5 \mathrm{~min}$ and cells were incubated $10 \mathrm{~min}$ with ProteinBlock (Dako, Glostrup, Denmark). The samples were incubated with PPAR $\alpha$ primary antibody (GeneTex, Hsinchu, Taiwan, cat. no. GTX28934) at dilution 1:200 overnight at $4{ }^{\circ} \mathrm{C}$. The reaction was visualised by Mouse/Rabbit PolyDetector DAB HRP Brown kit (Bio SB, Santa Barbara, USA, cat. no. BSB 
0205). Tris buffer with TWEEN 20 (pH 7.6) was used for washing between the different steps. Nuclei were counterstained with haematoxylin, washed in tap water, dehydrated, and cover slipped. The staining results were evaluated as the $\%$ of cells from 5 independent fields of vision at a magnification of 400x.

\subsection{Multiplex Immunofluorescence Staining}

To confirm that the villin expression was independent of the subcellular localisation of $\operatorname{PPAR} \alpha$, we used an Opal ${ }^{\mathrm{TM}}$ 4-Color Manual IHC Kit (Perkin Elmer, Walthem, USA, cat. no. NEL810001KT) according to the vendor's protocol. The undifferentiated HT-29 cells were seeded in 8-well cell culture slides, adhered overnight, and treated with $150 \mu \mathrm{M}$ fenofibrate and $10 \mu \mathrm{M}$ GW6471 for $72 \mathrm{~h}$. After that, the cells were fixed with $4 \%$ paraformaldehyde for $10 \mathrm{~min}$ at RT and were stained. The rabbit monoclonal primary antibody anti-villin (Abcam, Cambridge, UK, cat. no. ab130751) at dilution of 1:100 and PPAR $\alpha$ (GeneTex, Hsinchu, Taiwan, cat. no. GTX28934) at a dilution of 1:100 was used.

\subsection{Oil Red O Staining and Quantification of Lipid Content}

The cells were seeded in 8-well cell culture slides and adhered overnight. The next day, the undifferentiated cells were treated with $150 \mu \mathrm{M}$ fenofibrate, $200 \mu \mathrm{M}$ WY-14643, and $10 \mu \mathrm{M}$ GW6471 and incubated for $72 \mathrm{~h}$. The differentiated cells were pre-treated with $5 \mathrm{mM}$ sodium butyrate for $72 \mathrm{~h}$; after that, the medium was changed and the cells were treated with $150 \mu \mathrm{M}$ fenofibrate, $200 \mu \mathrm{M}$ WY-14643, and $10 \mu \mathrm{M}$ GW6471 and incubated for $72 \mathrm{~h}$. After the incubation period, the samples were washed with PBS and fixed with $4 \%$ paraformaldehyde for $10 \mathrm{~min}$ at RT. The cells were washed in 60\% isopropyl alcohol and then stained with Oil Red O solution (0.3\% Oil Red O (Sigma-Aldrich, St. Louis, USA; cat. no. O0625) in 60\% isopropyl alcohol) for $45 \mathrm{~min}$. Then, the slides were washed in $60 \%$ isopropyl alcohol followed with water. The cell nuclei were counterstained with haematoxylin and the slides were cover slipped in AquaTex mounting medium (Dako, Glostrup, Denmark, cat. no. S3025).

For quantification, the cells were seeded in 96-well plates as well as for ICE method mentioned above. After incubation, the cells were washed with PBS and fixed with $4 \%$ paraformaldehyde for $10 \mathrm{~min}$ at RT, then washed with $60 \%$ isopropyl alcohol. Then, $100 \mu \mathrm{L}$ of Oil red per well were added and incubated for $45 \mathrm{~min}$ at RT. The plate was washed six times with deionised water. Next, 60\% isopropyl alcohol was added for 10 min to elude the dye. The absorbance of extracted dye at $510 \mathrm{~nm}$ was measured by microplate reader Power Wave XS (Bio-Tek). The plates were washed and stained by Janus green (absorbance measured at $615 \mathrm{~nm}$ ) to account for the cell number. The normalised absorbance A510/A615 was calculated and the results are shown as the mean $\pm \operatorname{SD}(n=12)$.

\subsection{Immunohistochemical Detection of PPAR $\alpha$}

Tissue samples of colorectal adenocarcinoma and adjacent normal colon tissue (i.e., both samples from one patient) were obtained from the archives of the Department of Clinical and Molecular Pathology, Faculty of Medicine and Dentistry, Palacky University, Olomouc. The total number of patients was 37 (26 males, 11 females; all patients were Caucasians). No patient obtained any anticancer treatment before surgery. The average age of the patients was $66.54 \pm 11.30$ years, median 69.00 years (males: average $65.77 \pm 11.63$, median 69.00 years; females: average $68.36 \pm 10.80$ years, median 70.00 years). The sample collection contained grade $1(n=9)$, grade $2(n=20)$, and grade $3(n=8)$ carcinomas. The basic patients' characteristics (i.e., age, sex, grading, and TNM staging) are provided in Table S1. The use of all samples was approved by the Ethics Committee of the University Hospital Olomouc (protocol No. 134/14).

PPAR $\alpha$ was detected in $4 \mu \mathrm{m}$ thick paraffin sections. Slides were deparaffinised and hydrated by passage through a series of xylene, ethanol, and distilled water washes. Heatinduced antigen retrieval in citrate buffer $\mathrm{pH} 6$ was performed $\left(120^{\circ} \mathrm{C}, 15 \mathrm{~min}\right.$, Histos device). The samples were pre-treated with PolyDetector Peroxidase Blocker (Bio SB, part 
of the detection kit) for $5 \mathrm{~min}$, samples were incubated for $30 \mathrm{~min}$ with ProteinBlock (Dako, Glostrup, Denmark) and then incubated with PPAR $\alpha$ primary antibody (GeneTex, Hsinchu, Taiwan, cat. no. GTX28934) at dilution 1:100 for $1 \mathrm{~h}$ at RT. The reaction was visualised by Mouse/Rabbit PolyDetector DAB HRP Brown kit (Bio SB, Santa Barbara, USA, cat. no. BSB 0205). Tris buffer with TWEEN 20 (pH 7.6) was used for washing between the different steps. Nuclei were counterstained with haematoxylin. After washing in tap water, the samples were dehydrated and cover slipped.

Stained samples were semi-quantitatively evaluated twice at different times. Evaluation of staining intensity was performed as following: 0 for negative tissue, 1 for a weak signal, 2 for a moderate signal, and 3 for a strong signal. Additionally, for overall staining intensity of the samples, the crypt and epithelial surface areas were evaluated separately for normal colon tissue samples.

\subsection{Statistical Evaluation}

Results obtained from proliferation assay and In-Cell ELISA were evaluated by onesample $t$-tests. The \% of cells with nuclear positivity of PPAR $\alpha$ was evaluated by Fisher's exact test. The differences in PPAR $\alpha$ staining intensities between normal and tumour tissues as well as between crypt and surface epithelium in normal colon were evaluated by the Wilcox test. The differences in immunostaining among tumour grades were evaluated by the Kruskal-Wallis test. The lipid content in control and treated cells was evaluated using Student's $t$-tests. All calculations were performed by GraphPad Prism 8 (San Diego, USA) at the $p<0.05$ level of significance. Statistically significant differences are marked with an asterisk $\left.{ }^{*}\right)$ directly in graphs: ${ }^{*} p \leq 0.05,{ }^{* *} p \leq 0.01,{ }^{* * *} p \leq 0.001$, and ${ }^{* * *} p \leq 0.0001$.

\section{Results}

\subsection{Expression and Nuclear Localisation of PPAR $\alpha$ in Undifferentiated and Differentiated Intestinal Cells}

In colon tissue sections, the surface epithelium consists of differentiated cells whereas undifferentiated cells are located in crypts. We found a statistically significant increase in PPAR $\alpha$ expression in differentiated cells in comparison to undifferentiated ones $(n=37$, $p<0.0001$ ). The median of IHC staining intensity for the crypt area was 1 (weak staining), whereas the median of IHC staining intensity for surface epithelium was 2 (moderate staining). For results, see Figure $1 \mathrm{~A}$.

HT-29 cells represent an undifferentiated phenotype when grown in normal culture conditions. They can be differentiated in vitro under experimental culture conditions (incubation with $5 \mathrm{mM}$ sodium butyrate for $72 \mathrm{~h}$ ) [34]. In differentiated HT-29 cells, we found a 2.36-fold higher expression of PPAR $\alpha$ in comparison to undifferentiated ones $(p<$ $0.0001)$. We also detected slightly higher nuclear positivity of PPAR $\alpha$ in differentiated cells $(33.8 \%$ vs. $38.5 \%)$, but this difference was non-significant $(p=0.1974)$.

In next experiment, the PPAR $\alpha$ activators (fenofibrate and WY-14643) and PPAR $\alpha$ inhibitor (GW6471) were administrated to undifferentiated and differentiated (pre-treated with sodium butyrate) HT-29 cells. Fenofibrate, WY-14643 and GW6471 also increased PPAR $\alpha$ expression itself, and this effect was more pronounced in undifferentiated HT-29 cells treated with fenofibrate and GW6471. Administration of $150 \mu \mathrm{M}$ fenofibrate led to a 3.93-fold increase of PPAR $\alpha$ expression $(p=0.0023)$ in undifferentiated cells and a 1.92-fold increase $(p=0.0006)$ in differentiated cells. Administration of $200 \mu \mathrm{M} \mathrm{WY}-14643$ led to weaker but still significant increase: 1.16-fold for undifferentiated cells $(p=0.0203)$ and 1.34-fold for differentiated cells $(p=0.0019)$. Administration of GW6471 increased the PPAR $\alpha$ expression 5.17-fold in undifferentiated cells $(p=0.0002)$ and 1.51-fold increased $(p$ $=0.0006)$ in differentiated cells. For results, see Figure $1 \mathrm{C}$. 
A) PPAR $\alpha$ in normal colon tissue

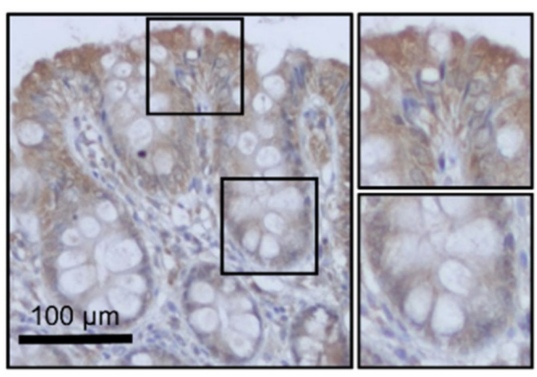

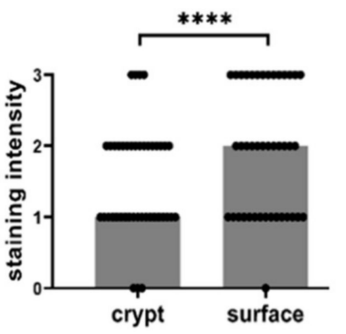

B) PPAR $\alpha$ expression in HT-29 cells

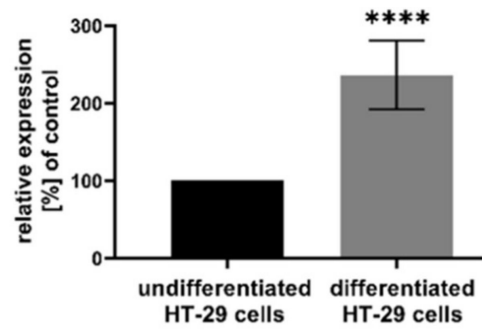

C) Effect of fenofibrate, WY-14643 and GW6471

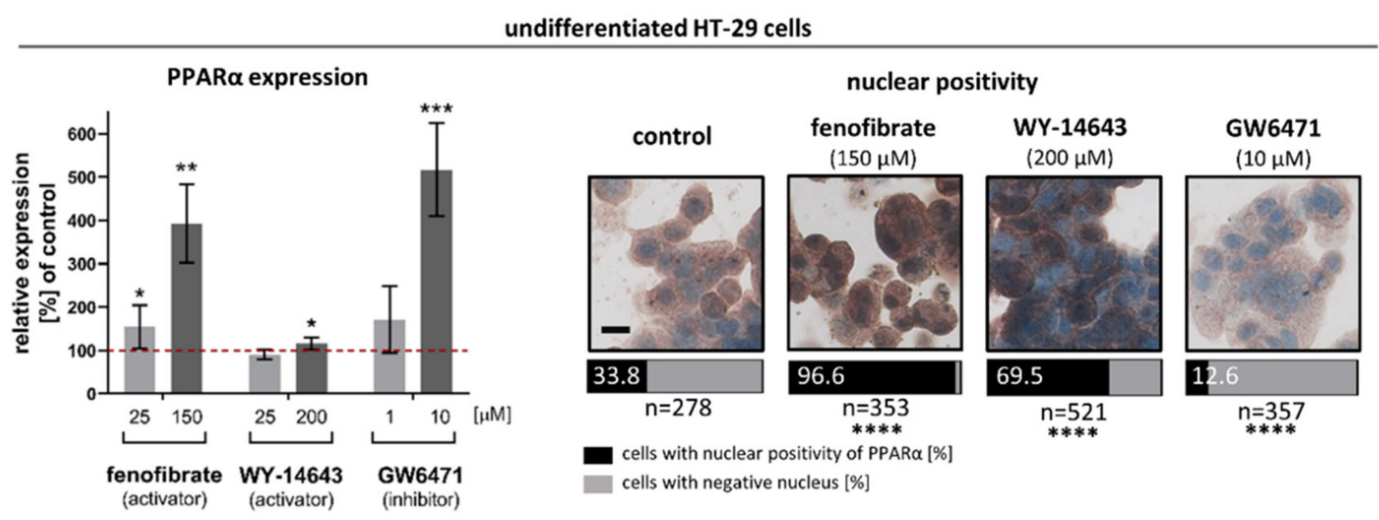

differentiated HT-29 cells

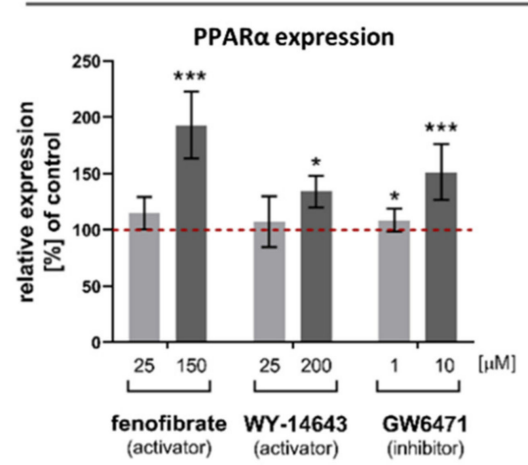

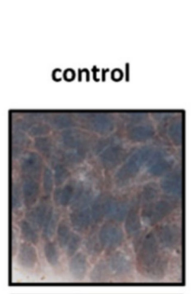

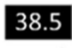

$n=564$

cells with nuclear positivity of PPAR $\alpha$ [\%]

cells with negative nucleus [\%]

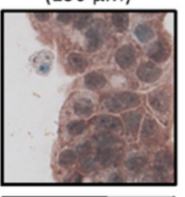

61.0

$=349$ nuclear positivity $(150 \mu \mathrm{M}) \quad(200 \mu \mathrm{M})$

GW6471

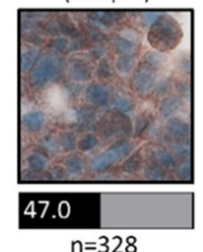

$\mathrm{n}=328$

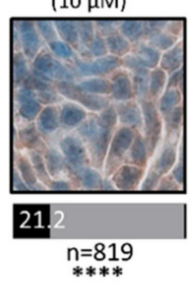

Figure 1. Expression and nuclear localisation of PPAR $\alpha$ in undifferentiated and differentiated intestinal cells: (A) Comparison of immunostaining intensity in crypt area (undifferentiated cells) and surface epithelium (differentiated cells). The immunohistochemical (IHC) profile is shown as medians of staining intensities of all samples. Staining intensities were evaluated semi-quantitatively: negative (0), weak (1), moderate (2) and strong (3). The results were evaluated by Wilcox test, $n=37$. Magnification 200x, details 400x, antibody signal brown, nuclei blue. (B) Relative change of PPAR $\alpha$ expression between undifferentiated and differentiated HT-29 cells measured by In Cell-ELISA. Black columns represent controls, undifferentiated or differentiated cells (100\%). Results are shown as mean $\pm \operatorname{SD}(n=6)$ and evaluated by one sample t-test. (C) Effect of PPAR $\alpha$ activators (fenofibrate and WY-14643) and PPAR $\alpha$ inhibitor (GW6471) on PPAR $\alpha$ expression and subcellular localisation in HT-29 cells. Relative expression of PPAR $\alpha$ in comparison to control was measured by In-Cell ELISA. Results are shown as the mean $\pm \operatorname{SD}(n=6)$ and evaluated by one-sample $t$-test. The red dotted lines represent control cells: DMSO treated undifferentiated or differentiated cells $(100 \%)$. Nuclear positivity of PPAR $\alpha$ was evaluated as the $\%$ of cells with nuclear PPAR $\alpha$ positivity from 5 fields of vision. The results were evaluated by Fisher's exact test. Fenofibrate and WY-14643 favoured nuclear positivity of PPAR $\alpha$, whereas GW6471 retained PPAR $\alpha$ in cell cytoplasm. All microphotographs are in the same magnification (400x); the black line represents $10 \mu \mathrm{m}$; brown - antibody signal; blue -nuclei. Statistically significant results in comparison to control cells are marked directly in the graphs: ${ }^{*} p \leq 0.05$, ${ }^{* *} p \leq$ $0.01,{ }^{* * *} p \leq 0.001,{ }^{* * * *} p \leq 0.0001$. 
We also explored the subcellular localisation of the receptor of interest. The fenofibrate, WY-14643 and GW6471 treatment affected nuclear localisation of PPAR $\alpha$ receptor in both undifferentiated and differentiated HT-29 cells. As expected, treatment with $150 \mu \mathrm{M}$ fenofibrate and $200 \mu \mathrm{M} W Y-14643$ led to a significant increase in nuclear positivity of PPAR $\alpha$ in comparison to control cells $(p<0.0001$ for both compounds in undifferentiated cells and with $p<0.0001$ for fenofibrate and $p=0.0079$ for WY-1463 in differentiated cells). Contrary to PPAR $\alpha$ activators, GW6471 caused a significant decrease in nuclear positivity of PPAR $\alpha$ in comparison to control cells as expected $(p<0.0001$ for undifferentiated and differentiated cells).

\subsection{Effect of Fenofibrate, WY-14643 and GW6471 on the Cell Proliferation Activity of HT-29}

The effects of fenofibrate, WY-14643 and GW6471 treatment on cell proliferation for undifferentiated and differentiated HT-29 are summarised in Figure 2A.

In undifferentiated HT-29 cells, lower concentration $(25 \mu \mathrm{M})$ of PPAR $\alpha$ activators fenofibrate and WY-14643 showed an increase in cell proliferation: $131.70 \pm 19.71 \%$ of control $(p=0.0228)$ for fenofibrate and $116.4 \pm 19.67 \%$ of control $(p=0.0366)$ for WY-14643. The higher concentrations of PPAR $\alpha$ activators $(150 \mu \mathrm{M}$ fenofibrate and $200 \mu \mathrm{M}$ WY-14643) showed a significant decrease in proliferation activity to $89.41 \pm 8.28 \%$ of the control $(p=0.0259)$ and $81.81 \pm 18.87 \%$ of the control $(p=0.0384)$, respectively. Administration of PPAR $\alpha$ inhibitor GW6471 showed a concentration-dependent decrease in cell proliferation activity: $89.57 \pm 19.18 \%$ of the control for $1 \mu \mathrm{M} \mathrm{GW6471} \mathrm{(non-significant,} p=0.2403$ ) and $66.49 \pm 8.87 \%$ of the control for $10 \mu \mathrm{M} \mathrm{GW6471}(p<0.0001)$.

In differentiated HT-29 cells, we found a concentration-dependent decrease in proliferation activity after treatment with all compounds. The obtained results (as a $\%$ of the control) were: $84.31 \pm 21.40 \%$ for $25 \mu \mathrm{M}$ fenofibrate $(p=0.1005)$ and $71.61 \pm 14.78 \%$ for $150 \mu \mathrm{M}$ fenofibrate $(p=0.0004), 93.85 \pm 13.69 \%(p=0.2448)$ for $25 \mu \mathrm{M}$ WY-14643 and 82.90 $\pm 24.23 \%(p=0.1444)$ for $200 \mu \mathrm{M} W Y-14643(p=0.1441)$, and $100.10 \pm 24.66 \%$ for $1 \mu \mathrm{M}$ GW6471 $(p=0.9951)$ and $81.32 \pm 17.26 \%(p=0.0118)$ for $10 \mu \mathrm{M}$ GW6471. 
A) Effect of PPAR $\alpha$ ligands on HT-29 cells

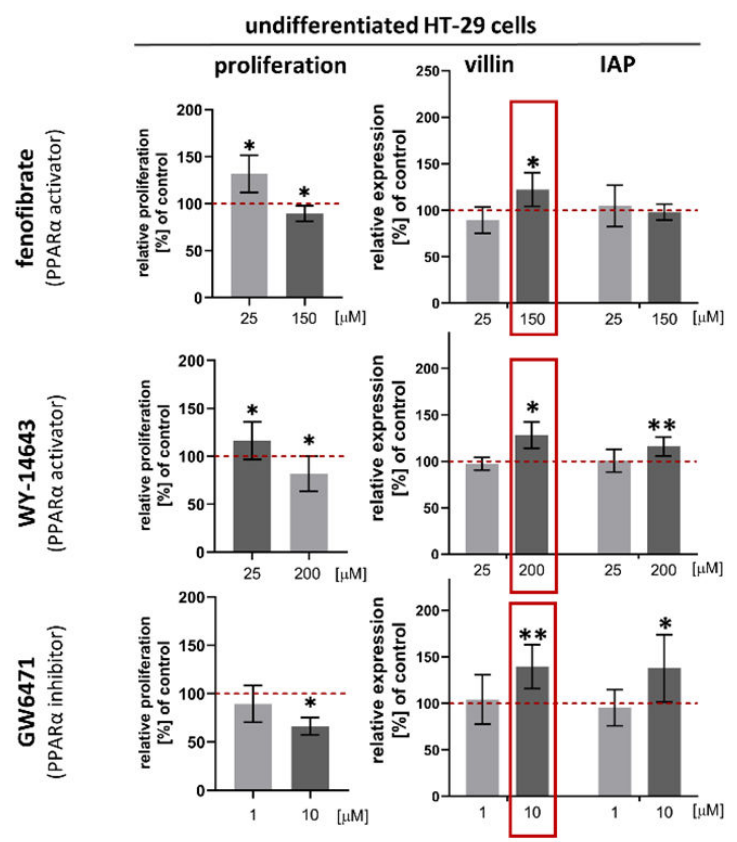

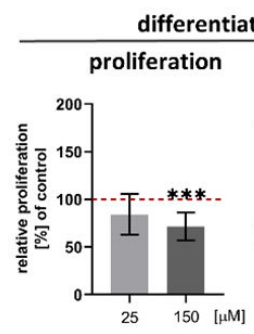
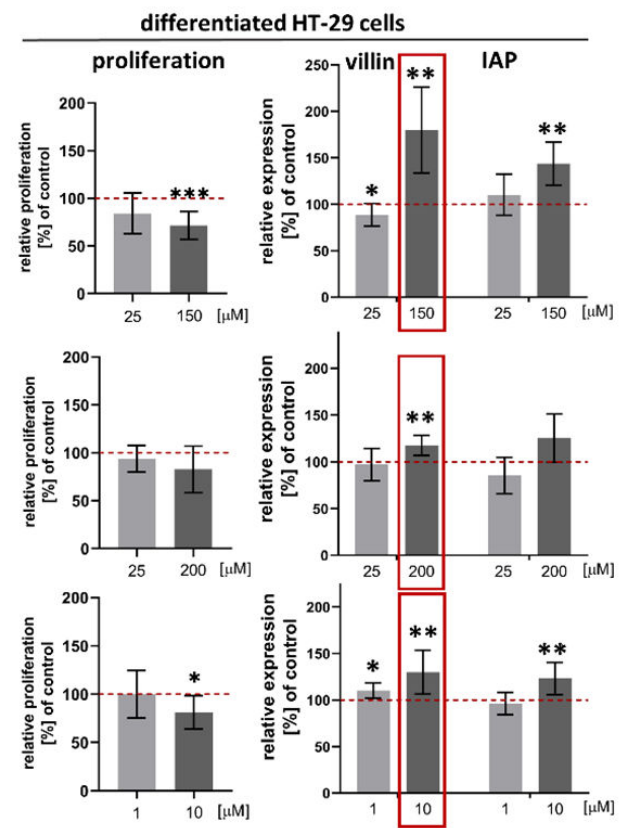

B) PPAR $\alpha$ and villin colocalization
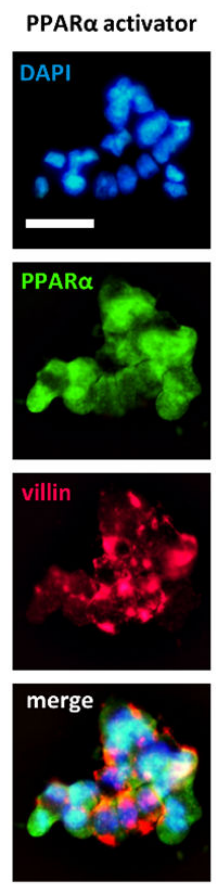

C) Effect of PPAR $\alpha$ ligands on Caco2 cells
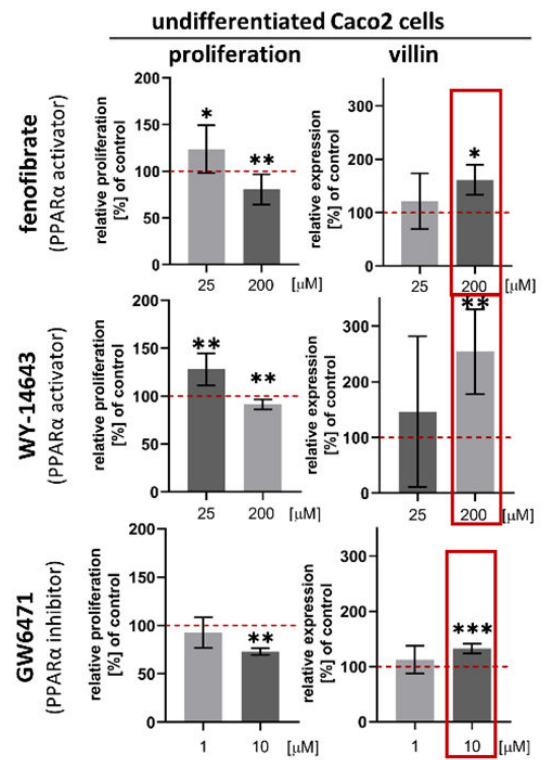
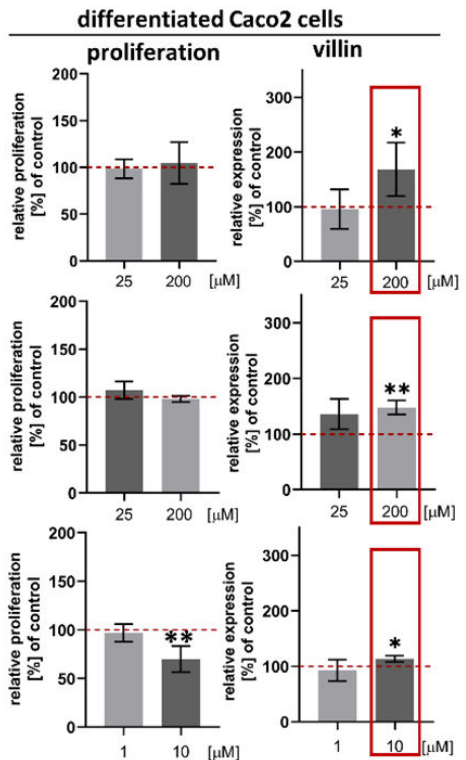

Figure 2. Effects of PPAR $\alpha$ activators (fenofibrate and WY-14643) and PPAR $\alpha$ inhibitor (GW6471) on cell proliferation and differentiation: (A) The effect of PPAR $\alpha$ ligands on undifferentiated and sodium butyrate differentiated HT-29 cells. Relative cell proliferation measured by WST-1 assay. Results are shown as the mean $\pm \mathrm{SD}(n=9)$. Relative expression of villin and intestinal alkaline phosphatase (IAP) in comparison to the control was measured by In-Cell ELISA. Results are shown as the mean $\pm \mathrm{SD}(n=6)$. The red dotted lines represent control cells: DMSO-treated undifferentiated or differentiated cells $(100 \%)$. (B) Co-localisation of PPAR $\alpha$ and villin expression in HT-29 cells. The cells were treated with $150 \mu$ M fenofibrate (PPAR $\alpha$ activator) and $10 \mu \mathrm{M}$ GW6471 (PPAR $\alpha$ inhibitor). Fenofibrate treatment favoured nuclear localisation of PPAR $\alpha$, whereas GW6471 treatment retained PPAR $\alpha$ in cytoplasm. The villin expression was independent of subcellular localisation of PPAR $\alpha$. All microphotographs are in the same magnification (400x); the white line represents $10 \mu \mathrm{m}$. (C) Effect of PPAR $\alpha$ ligands on undifferentiated and spontaneously differentiated Caco2 cells. Relative cell proliferation measured by WST-1 assay. Results are shown as the mean \pm SD $(n=9)$. Relative expression of villin in comparison to the control was measured by In-Cell ELISA. Results are shown as the mean $\pm \mathrm{SD}(n=6)$. The red dotted line represents control cells: DMSO-treated undifferentiated or differentiated cells $(100 \%)$. Note the increase in villin expression in both used cell lines after PPAR $\alpha$ treatment (red rectangles). Statistically significant results in comparison to control cells are marked by ${ }^{*} p \leq 0.05,{ }^{* *} p \leq 0.01,{ }^{* * *} p \leq 0.001$. 


\subsection{Effects of Fenofibrate, WY-14643 and GW6471 on Expression of Intestinal Differentiation} Markers (Villin and IAP) in HT-29 Cells

The effects of fenofibrate, WY-14643 and GW6471 on expression of villin and IAP in HT-29 cells was dose-dependent. For the results, see Figure 2A. In general, the treatment with higher concentrations (concentrations decreasing cell proliferation response) of PPAR $\alpha$ activators led to a significant increase in villin expression; the increase in IAP expression was less convincing. Fenofibrate treatment increased the villin expression 1.22-fold $(p=0.0100)$ in undifferentiated cells and 1.80 -fold $(p=0.0019)$ in differentiated cells. The IAP expression was unchanged in undifferentiated cells, and there was a 1.52-fold increased $(p=0.0012)$ in differentiated cells. WY-14643 increased the villin expression 1.17-fold $(p=0.0099)$ in undifferentiated cells and 1.34-fold $(p=0.0019)$ in differentiated cells. The IAP expression was 1.16-fold increased $(p=0.0029)$ in undifferentiated cells and 1.25-fold increased $(p=0.1436)$ in differentiated cells.

Surprisingly, the administration of PPAR $\alpha$ inhibitor GW6471 showed a very similar pattern of changes in the expression of proteins of interest as PPAR $\alpha$ activators. A significant increase in the expression of villin and IAP was clearly apparent after treatment with higher $(10 \mu \mathrm{M}) \mathrm{GW} 6471$ concentrations. The villin expression was 1.40-fold higher $(p=0.0020)$ in undifferentiated cells and 1.30-fold higher $(p=0.0087)$ in differentiated cells. The IAP expression increased by 1.38-fold $(p=0.0211)$ in undifferentiated cells and 1.23 -fold $(p=0.0067)$ in differentiated cells.

In addition to the ICE results, co-localisation of PPAR $\alpha$ and villin expression using multiplex immunofluorescent staining confirmed that villin expression was not dependent on subcellular localisation of PPAR $\alpha$, neither PPAR $\alpha$ activation (fenofibrate) nor inhibition (GW6471). For the results, see Figure 2B.

\subsection{Confirmation of the Effect of Fenofibrate, WY-14643 and GW6471 on Cell Proliferation Activity and Villin Expression in Caco2 Cell Line}

To confirm that PPAR $\alpha$ activators as well as PPAR $\alpha$ inhibitor led to the same result in terms of an increase in villin expression, we also conducted the experiments with the Caco2 cell line. To obtain differentiated $\mathrm{Caco} 2$, we used the post-confluent growth for 14 days. Thus, in this case, the differentiation phenotype was not induced by the addition of any compound.

In undifferentiated Caco2 cells, the proliferation response resembled the trends observed in HT-29 cells. The lower concentration $(25 \mu \mathrm{M})$ of PPAR $\alpha$ activators led to significant increase in cell proliferation: $123.7 \pm 25.62 \%$ of the control for fenofibrate and $128.0 \pm 14.93 \%$ of the control for WY-14643 ( $p=0.0498$ and $p=0.0058$ ). Higher concentrations $(200 \mu \mathrm{M})$ of PPAR $\alpha$ activators led to a significant decrease in cell proliferation to $80.59 \pm 16.15 \%$ of the control for fenofibrate and $91.35 \pm 5.162 \%$ of the control for WY-14643 ( $p=0.0069$ and $p=0.0093)$. Administration of PPAR $\alpha$ inhibitor (GW6471) in a higher concentration $(10 \mu \mathrm{M})$ led to a significant decrease in cell proliferation $(p=0.0002)$. Used compound did not significantly affect proliferation of differentiated Caco2 cells in comparison to untreated differentiated cells. Only the decrease in proliferation caused by the $10 \mu \mathrm{M}$ GW6471 was significant $(70.1 \pm 11.86 \%$ of the control, $p=0.0016)$.

The villin expression in Caco2 cells showed the same patterns as the HT-29. In undifferentiated cells, administration of PPAR $\alpha$ activators in the concentration of $200 \mu \mathrm{M}$ increased the expression of villin 1.61-fold for fenofibrate and 2.54-fold for WY-14643 ( $p=0.0226$ and $p=0.0026$ ). Treatment with $10 \mu \mathrm{M}$ GW6471 led to a 1.32-fold increase in villin expression $(p=0.0002)$. The increase in villin expression was also observed in differentiated Caco2 cells treated with fenofibrate, WY-14643 and GW6471. The increase was 1.68-fold, 1.37-fold and 1.13-fold, respectively, $(p=0.0357, p=0.0251$ and $p=0.0187)$. 


\subsection{Effects of Fenofibrate, WY-14643 and GW6471 on Lipid Content}

In untreated (control) cells, we observed significant accumulation of lipids in differentiated HT-29 cells in comparison to undifferentiated ones $(p=0.0015)$. The lipid content in differentiated HT-29 cells was twofold higher than in undifferentiated cells. Treatment with $150 \mu \mathrm{M}$ fenofibrate led to a strongly significant increase in lipid accumulation in both undifferentiated and differentiated cells in comparison to the controls $(p<0.0001$ for both undifferentiated and differentiated cells). Treatment with $10 \mu \mathrm{M}$ GW6471 also led to lipid accumulation to a lesser extent than fenofibrate treatment, but the differences between GW6471 treated and control cells were significant $(p<0.0001$ for undifferentiated cells, $p=0.0054$ for differentiated cells). Contrary to lipid accumulation after fenofibrate and GW6471 treatment, administration of WY-14643 had no effect on the lipid content. For the results, see Figure 3.
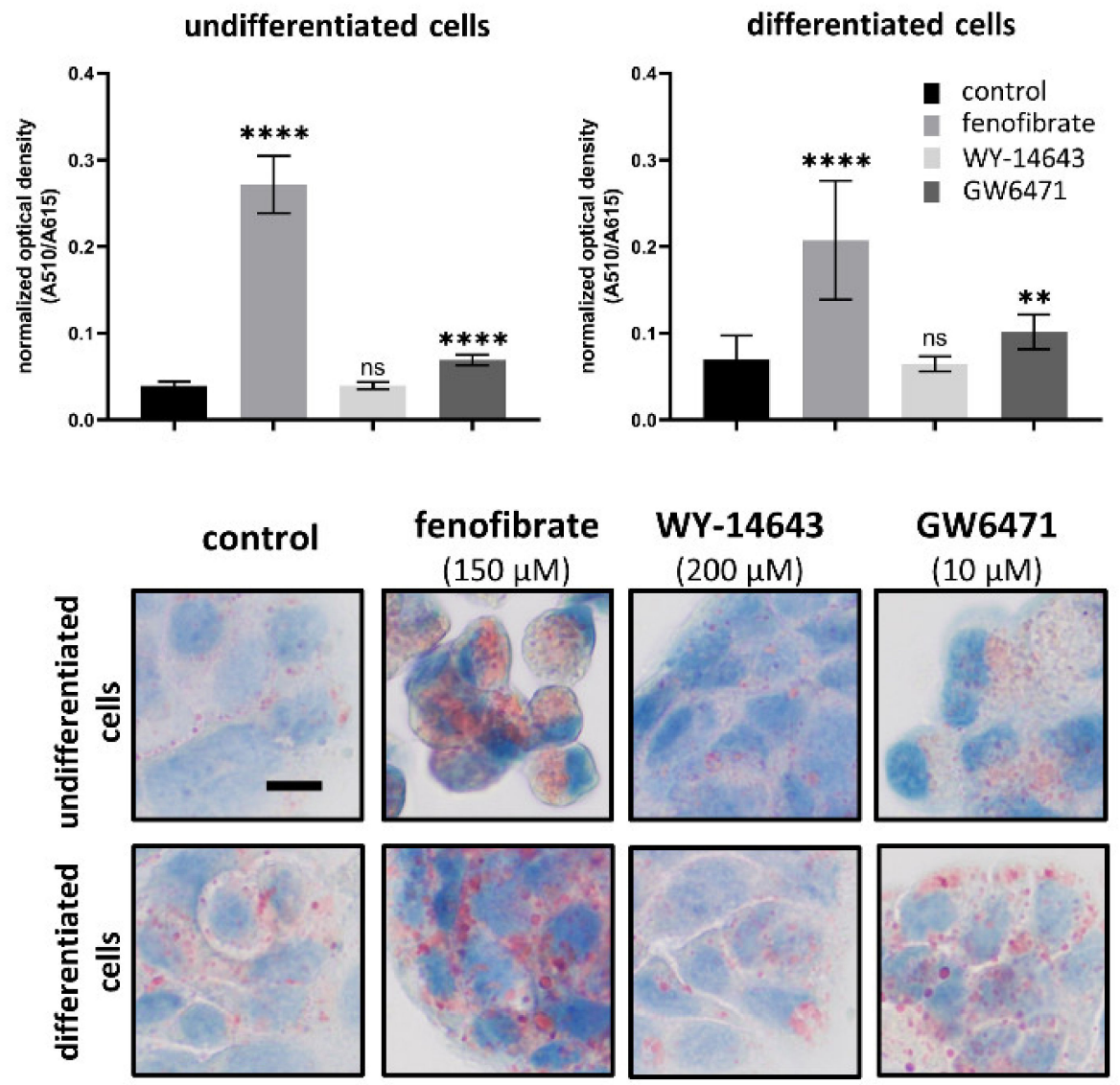

Figure 3. Lipid content in undifferentiated and differentiated HT-29 cells after treatment with PPAR $\alpha$ activators (fenofibrate and WY-14643) and PPAR $\alpha$ inhibitor (GW6471). The used concentrations were $150 \mu \mathrm{M}$ for fenofibrate, $200 \mu \mathrm{M}$ for WY-14643 and $10 \mu \mathrm{M}$ for GW6471. Lipid content was quantified as absorbance obtained after Oil Red O staining (A510) normalised to Janus green whole-cell staining (A615). Results are shown as the mean \pm SD $(n=12)$ and evaluated by the Student's $t$-test. Statistically significant results in comparison to control cells are marked by ${ }^{* *} p \leq 0.01$ and ${ }^{* * *} p \leq 0.0001$. All microphotographs are at the same magnification (400x); the black line represents $10 \mu \mathrm{m}$; red lipid droplets; nuclei -blue.

\subsection{Comparison of PPAR in Tumour and Adjacent Normal Tissue Samples}

We found no difference between PPAR $\alpha$ immunostaining intensities between tumour and adjacent normal tissue samples ( $p=0.6182, n=37)$. We also found no differences in IHC staining intensities between tumours and adjacent normal tissue samples when we analysed each tumour grade separately with $p=0.3750, p=0.2323$ and $p=0.6875$ for 
grade 1, grade 2 and grade 3, respectively. Moreover, there were no significant differences in immunostaining intensities of grade 1 , grade 2 and grade 3 tumours $(p=0.3924)$. The decrease in expression of PPAR $\alpha$ in carcinoma samples in comparison to normal tissue was detected in $15 / 37$ patients (i.e., $40.5 \%$ ), the increase in $14 / 37$ (37.8\%) patients and $8 / 37(21.6 \%)$ patients samples showed the same staining intensity for normal and tumour tissue samples. Moreover, we found no differences in PPAR $\alpha$ expression in tumours between males and females $(p=0.6875)$ as well as when we evaluated differences between tumours and adjacent normal tissues for males and females separately with $p=0.4112$ and $p=0.5870$. Because no differences among tumour grades were detected, the immunostaining intensities in Figure 4 were grouped and represented all together. The columns show medians of staining intensity, each dot represents one patient $(n=37)$. The results are accompanied by representative microphotographs of grade 1, grade 2 and grade 3 tumours and adjacent normal tissues from the same patient.

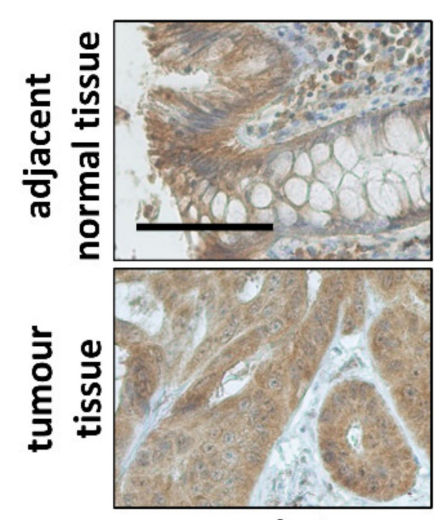

grade 1

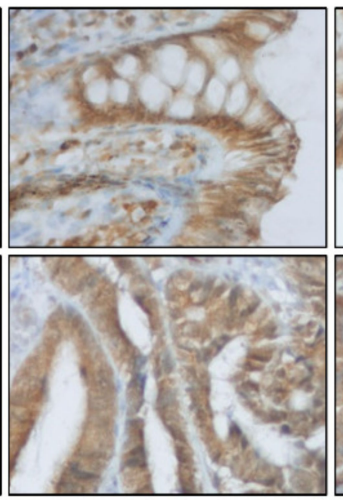

grade 2

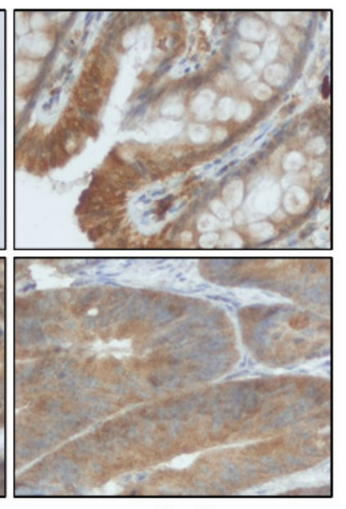

grade 3

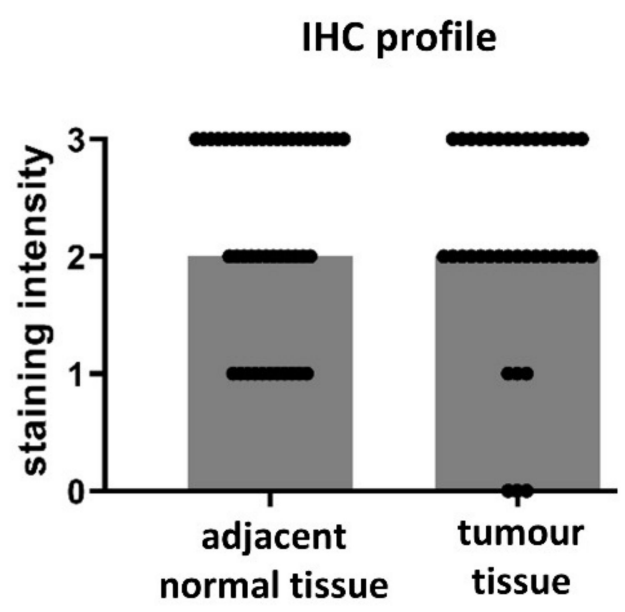

Figure 4. Expression of PPAR $\alpha$ in colorectal carcinoma and adjacent normal tissues. Representative microphotographs of grade 1, grade 2 and grade 3 tumours and adjacent normal tissue samples from the same patient. The immunohistochemical (IHC) profile is shown as the medians of staining intensities of all samples. Because there were no differences between tumours and adjacent normal tissues in grade 1, grade 2 and grade 3 tumours, all results for IHC staining are represented together $(n=37)$. Columns represent medians of immunostaining intensities; each dot represents one patient. Magnification 100x; black line represents $100 \mu \mathrm{m}$; brown - antibody signal; blue - nuclei.

\section{Discussion}

PPAR $\alpha$ is involved in various cellular functions including differentiation of various cell types. The aim of this study was to investigate the possible role of PPAR $\alpha$ in intestinal cell differentiation using in vitro differentiated HT-29 and Caco2 cells and tissue samples of normal epithelium as well as colorectal carcinoma.

Our results showed an increase in PPAR $\alpha$ expression in differentiated cells of both colon tissue samples as well as in vitro differentiated HT-29 cells. The increase in PPAR $\alpha$ expression in differentiated HT-29 cells resembled the expression of villin described in our previous study [34]. In differentiated HT-29 cells, we detected 2.36-fold and 2.15fold higher levels of PPAR $\alpha$ and villin, respectively. An Increase in PPAR $\alpha$ expression in differentiated intestinal cells has previously been described. It was shown that PPAR $\alpha$ expression is stronger in the apical part of villi in mouse small intestine [30] as well as in in vitro differentiated $\mathrm{Caco} 2$ cell line which was accompanied by an increase in the nuclear positivity of PPAR $\alpha$ [32]. Although the expression of PPAR $\alpha$ increased, the nuclear positivity remained comparable between undifferentiated and differentiated HT-29 cells in our experiment.

The first prerequisite for the regulation of gene expression is the nuclear localisation of the receptor. It has been shown that PPAR $\alpha$ shuffle between cytoplasm and nu- 
cleus [35], and nuclear localisation is favoured by ligand binding. Our results confirmed an increase in nuclear subcellular localisation of PPAR $\alpha$ after administration of PPAR $\alpha$ activators. Contrary to this, PPAR $\alpha$ inhibitor reduced PPAR $\alpha$ nuclear positivity as expected. This phenomenon was observable regardless of the differentiation status of HT-29 cells; however, it was more pronounced in undifferentiated cells.

Both PPAR $\alpha$ activators (fenofibrate and WY-14643) as well as PPAR $\alpha$ inhibitor (GW6471) affected cell proliferation activity. Cell treatment with $150 \mu \mathrm{M}$ fenofibrate, $200 \mu \mathrm{M}$ WY-14643 and $10 \mu \mathrm{M}$ GW6471 led to significant decreases in cell proliferation of HT-29 cells, regardless of the differentiation status. The significant decreases in cell proliferation after treatment with $200 \mu \mathrm{M}$ fenofibrate, WY-14643 and $10 \mu \mathrm{M}$ GW6471 were detected also in undifferentiated Caco2 cells. The decrease in cell proliferation is in accordance with previous studies performed in various human cell types treated with fenofibrate [11-14,36-43], WY-14643 [44,45] or GW6471 [46-48]. An increase in cell proliferation, observed in undifferentiated cells after treatment with lower concentration of fibrates, was also previously described $[17,18]$.

The undifferentiated and differentiated HT-29 cells showed similar response to treatment with PPAR $\alpha$ activator and inhibitor regardless of their differentiation status. The administration of PPAR $\alpha$ activators led to an increase in villin and IAP expression suggested the role of PPAR $\alpha$ activation in intestine cell differentiation. Surprisingly, the administration of PPAR $\alpha$ inhibitor led to the same results. Moreover, we proved that HT-29 cells expressed villin independently on PPAR $\alpha$ subcellular localisation. The same trend in villin expression was also observed in Caco2 cell line. Although it may seem at first glance that PPAR $\alpha$ may play a role in differentiation of intestinal cells due to the fact of its higher expression in differentiated cells in comparison to undifferentiated ones, our data indicated intestinal cell differentiation was PPAR $\alpha$ independent. We suppose that the increase in differentiation markers after fenofibrate, WY-14643 and GW6471 was related to the decrease in cell proliferation rather than direct PPAR $\alpha$ activation or inhibition.

According to available literature, villin functions are regulated via PI3K/Akt-mediated signalling, because association of villin with phosphatidylinositol(4,5)-bisphosphate (PIP2) enhances its actin bundling function and, thus, formation of brush border [49-51]. PI3K phosphorylates PIP2 to phosphatidylinositol(3,4,5)-trisphosphate (PIP3). An increase in expression of markers of differentiation was observed after concentration of fenofibrate and GW6471 that inhibit cell proliferation activity, which could be mediated via the PI3K/Akt pathway. It has been shown that GW6471 decreases the expression of PI3K in cells of head and neck paragangliomas [46]. The same effect, a decrease in PI3K, has been observed in human gastric cancer cell lines after fenofibrate treatment [37]. A decrease in PI3K could be associated with PIP2 accumulation and thereby the actin bundling function of villin. In colorectal carcinoma cells HCT-116, inhibition of PI3K has led to an increase in alkaline phosphatase activity [52]. Moreover, it has been shown that fenofibrate suppresses growth via a decrease in phosphorylation of Akt, and this effect is PPAR $\alpha$ independent in hepatocellular carcinoma cells [36] as well as in angiosarcoma cells [38]. However, if upstream molecules, such as PI3K, are also affected, they have not been described yet. The observed effect of WY-14643 on villin expression in our study may also be PPAR $\alpha-$ independent. Except involvement of the PI3K pathway, intestinal cell differentiation has also been associated with activation of p38 MAPK [53,54], and it has been shown that WY-14643 induces phosphorylation of this protein [55-57].

PPAR $\alpha$ is known as a lipid sensor. PPAR- $\alpha$ controls the expression of numerous genes related to lipid metabolism, including genes involved in mitochondrial $\beta$-oxidation, peroxisomal $\beta$-oxidation, fatty acid uptake and binding and lipoprotein assembly and transport [5]. It has been shown that HT-29 cells cultured with sodium butyrate increases the amount of lipid droplets [58,59]. We also observed an increase in lipid droplet accumulation in sodium butyrate differentiated HT-29 cells. Thus, it could seem to be associated with differentiation of intestinal cell. However, understanding of this phenomenon is elusive. Lipid droplet accumulation is a well-known hallmark of cancer, including colorectal carci- 
noma, and it has been associated with cancer proliferation and aggressiveness [48,60-64]. Moreover, it has been shown that stimulation of lipid droplet density promoted proliferation in colon cancer cells [65]. The effect of PPAR $\alpha$ ligands on lipid droplet accumulation is not clear. Previous studies have shown that although fenofibrate has lowered lipid content in C2C12 myotubes [66], the same compound has caused dose-dependent lipid droplets accumulation in HepG2 cells [67]. GW6471 has decreased lipid droplets in breast cancer cells [48]. We observed enhanced lipid droplet accumulation in cells treated with fenofibrate as well as GW6471. Contrary to this, the second used PPAR $\alpha$ activator, WY-14643, had no effect on lipid accumulation. The observed lipid droplet accumulation was not associated with expression of villin and, thus, with intestinal cell differentiation.

Carcinogenesis is the disruption of normal differentiation process. PPAR $\alpha$ appears to play a role in carcinogenesis; however, it may act as a tumour suppressor or an oncoprotein $[11-19,46,47,68,69]$. Colorectal carcinoma is the third most common cancer in terms of incidence but the second in terms of mortality [70]. The role of PPAR $\alpha$ in colorectal cancer is inconclusive. At the tissue level, Luo et al. described reduced levels of PPAR $\alpha$ mRNA in colon cancer from mice. Moreover, activation of PPAR $\alpha$ by fenofibrate protected human PPAR $\alpha$ transgenic mice from chemical-induced colon cancer [71]. Contradictory results were described by Yaghoubizadeh et al. They detected overexpression of PPAR $\alpha$ mRNA in colorectal tumour tissues in comparison to adjacent normal tissues. This was negatively associated with clinico-pathological factors, such as tumour size, grade, TNM stage, metastases, lymphatic invasion and decrease in overall survival [31]. Using immunohistochemical detection of PPAR $\alpha$ in human tissue samples, Morinishi et al. described higher PPAR $\alpha$ positivity in carcinoma tissues than in normal epithelium. However, PPAR $\alpha$ expression was not related to sex, age, lymphatic invasion, venous invasion, lymph node metastasis, depth of invasion and stage [4]. In our tissue sample collection, we detected comparable levels of PPAR $\alpha$ in tumours in comparison to adjacent normal tissues. Moreover, there was no relation of PPAR $\alpha$ expression in tumours and tumour grades. These observations supported our results obtained for HT-29 and Caco2 cell lines-that differentiation of intestinal cell is PPAR $\alpha$ independent.

\section{Conclusions}

Taken together, our study revealed a significant increase in PPAR $\alpha$ expression in differentiated HT-29 cells as well as in normal surface colon epithelium where differentiated cells are localised. Interestingly, we found that both, PPAR $\alpha$ activators, fenofibrate and WY-14643 as well as its inhibitor GW6471 regulated proliferation and differentiation of HT-29 cells in vitro in the same way. Both compounds led to a decrease in proliferation accompanied with an increase in expression of villin and IAP. The same trend in villin expression was confirmed in Caco2 cells. Furthermore, villin expression was independent of subcellular localisation of PPAR $\alpha$. Moreover, we found similar levels of PPAR $\alpha$ expression in colorectal carcinomas in comparison to adjacent normal epithelium. All these findings support the hypothesis that differentiation of intestinal epithelium is PPAR $\alpha$ independent.

Supplementary Materials: The following are available online at https://www.mdpi.com/article/10 .3390/biomedicines9091255/s1, Table S1: Characteristics of tissue samples used in this study. All patients were Causasians with no anticancer therapy before surgery. c.-colon, T-primary tumour, Nlymph nodes, M-distant metastases, G1-grade 1, G2-grade 2, G3-grade 3; Figure S1: Schematic summarization of experimental procedure. The experimental procedure for undifferentiated cells of both cell lines were following: the cells were seeded, adhered overnight (o.n.), treated with PPAR $\alpha$ ligands or DMSO (controls), incubated for $72 \mathrm{~h}$ and then the analysis was performed (proliferation assay, In-Cell ELISA, immunofluorescent and immunocytochemical staining). To obtain differentiated cells, the cells were pre-treated with $5 \mathrm{mM}$ sodium butyrate $(\mathrm{NaBt})$ for $72 \mathrm{~h}$ (HT-29) or growth for 14 days after reaching confluence (Caco2). After differentiation procedure, the medium was changed and the cells were treated with PPAR $\alpha$ ligands or DMSO (controls), incubated for $72 \mathrm{~h}$ and then the analysis was performed. The cells were seeded on 96-well culture plates or 8-well culture slides, seeding density dependent on the assay and cell line. 
Author Contributions: C.K., F.T., H.J., and K.Z. conducted the cell culture experiments and data evaluation; T.Z. evaluated the immunohistochemistry; C.K. and T.Z. designed the study and performed data interpretation; C.K. and T.Z. wrote the manuscript. All authors have read and agreed to the published version of the manuscript.

Funding: This work was partly supported by IGA_LF_2021_005.

Institutional Review Board Statement: The study was conducted in accordance with the Declaration of Helsinki, and the protocol was approved by the Ethics Committee (protocol No. 134/14 dated 21 August 2014).

Informed Consent Statement: Informed consent was obtained from all subjects involved in the study.

Data Availability Statement: Data is contained within the article or Supplementary Materials. The patient data presented in this study are available in Supplementary File Table S1.

Acknowledgments: We thank Jiri Ehrmann from the Department of Clinical and Molecular Pathology and Laboratory of Molecular Pathology, Faculty of Medicine and Dentistry, Palacky University, Olomouc, for providing patient tissue samples. We thank Lucie Voznakova from the Department of Histology and Embryology, Faculty of Medicine and Dentistry, Palacky University, Olomouc, for technical support for immunohistochemistry.

Conflicts of Interest: The authors declare no conflict of interest.

\section{References}

1. Abbott, B.D.; Wood, C.R.; Watkins, A.M.; Das, K.P.; Lau, C.S. Peroxisome Proliferator-Activated Receptors Alpha, Beta, and Gamma mRNA and Protein Expression in Human Fetal Tissues. PPAR Res. 2010, 2010, 1-19. [CrossRef]

2. Pyper, S.R.; Viswakarma, N.; Yu, S.; Reddy, J.K. PPAR $\alpha$ : Energy Combustion, Hypolipidemia, Inflammation and Cancer. Nucl. Recept. Signal. 2010, 8, e002. [CrossRef]

3. Peters, J.M.; Shah, Y.M.; Gonzalez, F.J. The role of peroxisome proliferator-activated receptors in carcinogenesis and chemoprevention. Nat. Rev. Cancer 2012, 12, 181-195. [CrossRef]

4. Morinishi, T.; Tokuhara, Y.; Ohsaki, H.; Ibuki, E.; Kadota, K.; Hirakawa, E. Activation and Expression of Peroxisome ProliferatorActivated Receptor Alpha Are Associated with Tumorigenesis in Colorectal Carcinoma. PPAR Res. 2019, 2019, 1-9. [CrossRef]

5. Contreras, A.V.; Torres, N.; Tovar, A.R. PPAR- $\alpha$ as a Key Nutritional and Environmental Sensor for Metabolic Adaptation. Adv. Nutr. 2013, 4, 439-452. [CrossRef]

6. Bougarne, N.; Weyers, B.; Desmet, S.J.; Deckers, J.; Ray, D.W.; Staels, B.; De Bosscher, K. Molecular Actions of PPAR $\alpha$ in Lipid Metabolism and Inflammation. Endocr. Rev. 2018, 39, 760-802. [CrossRef] [PubMed]

7. Tokuno, A.; Hirano, T.; Hayashi, T.; Mori, Y.; Yamamoto, T.; Nagashima, M.; Shiraishi, Y.; Ito, Y.; Adachi, M. The effects of statin and fibrate on lowering small dense LDL- cholesterol in hyperlipidemic patients with type 2 diabetes. J. Atheroscler. Thromb. 2007, 14, 128-132. [CrossRef]

8. Keech, A.C.; Simes, R.J.; Barter, P.J.; Best, J.; Scott, R.A.P.; Taskinen, M.-R.; Forder, P.M.; Pillai, A.; Davis, T.M.; Glasziou, P.; et al. Effects of long-term fenofibrate therapy on cardiovascular events in 9795 people with type 2 diabetes mellitus (the FIELD study): Randomised controlled trial. Lancet 2005, 366, 1849-1861. [CrossRef] [PubMed]

9. Mazzon, E.; Cuzzocrea, S. Absence of Functional Peroxisome Proliferator-Activated Receptor-A Enhanced Ileum Permeability During Experimental Colitis. Shock 2007, 28, 192-201. [CrossRef] [PubMed]

10. Lee, J.W.; Bajwa, P.J.; Carson, M.J.; Jeske, D.R.; Cong, Y.; Elson, C.O.; Lytle, C.; Straus, D.S. Fenofibrate Represses Interleukin-17 and Interferon- $\gamma$ Expression and Improves Colitis in Interleukin-10-Deficient Mice. Gastroenterology 2007, 133, 108-123. [CrossRef]

11. Grabacka, M.; Płonka, P.M.; Urbanska, K.; Reiss, K. Peroxisome Proliferator-Activated Receptor $\alpha$ Activation Decreases Metastatic Potential of Melanoma Cells In vitro via Down-Regulation of Akt. Clin. Cancer Res. 2006, 12, 3028-3036. [CrossRef]

12. Panigrahy, D.; Kaipainen, A.; Huang, S.; Butterfield, C.E.; Barnés, C.M.; Fannon, M.; Laforme, A.M.; Chaponis, D.M.; Folkman, J.; Kieran, M.W. PPAR agonist fenofibrate suppresses tumor growth through direct and indirect angiogenesis inhibition. Proc. Natl. Acad. Sci. USA 2008, 105, 985-990. [CrossRef]

13. Li, T.; Zhang, Q.; Zhang, J.; Yang, G.; Shao, Z.; Luo, J.; Fan, M.; Ni, C.; Wu, Z.; Hu, X. Fenofibrate induces apoptosis of triple-negative breast cancer cells via activation of NF-kB pathway. BMC Cancer 2014, 14, 96. [CrossRef]

14. Hu, D.; Su, C.; Jiang, M.; Shen, Y.; Shi, A.; Zhao, F.; Chen, R.; Shen, Z.; Bao, J.; Tang, W. Fenofibrate inhibited pancreatic cancer cells proliferation via activation of p53 mediated by upregulation of LncRNA MEG3. Biochem. Biophys. Res. Commun. 2016, 471, 290-295. [CrossRef]

15. Su, C.; Shi, A.; Cao, G.; Tao, T.; Chen, R.; Hu, Z.; Shen, Z.; Tao, H.; Cao, B.; Hu, D.; et al. Fenofibrate suppressed proliferation and migration of human neuroblastoma cells via oxidative stress dependent of TXNIP upregulation. Biochem. Biophys. Res. Commun. 2015, 460, 983-988. [CrossRef] [PubMed] 
16. Saidi, S.A.; Holland, C.M.; Charnock-Jones, D.S.; Smith, S.K. In vitro and in vivo effects of the PPAR-alpha agonists fenofibrate and retinoic acid in endometrial cancer. Mol. Cancer 2006, 5, 13. [CrossRef]

17. Suchanek, K.M.; May, F.J.; Robinson, J.A.; Lee, W.J.; Holman, N.A.; Monteith, G.R.; Roberts-Thomson, S.J. Peroxisome proliferatoractivated receptor $\alpha$ in the human breast cancer cell lines MCF-7 and MDA-MB-231. Mol. Carcinog. 2002, 34, 165-171. [CrossRef] [PubMed]

18. Cizkova, K.; Steigerova, J.; Gursky, J.; Ehrmann, J. Stimulating effect of normal-dosing of fibrates on cell proliferation: Word of warning. Lipids Health Dis. 2016, 15, 164. [CrossRef]

19. Tauber, Z.; Koleckova, M.; Cizkova, K. Peroxisome proliferator-activated receptor $\alpha$ (PPAR $\alpha$ )-cytochrome P450 epoxygenasessoluble epoxide hydrolase axis in ER + PR + HER2- breast cancer. Med. Mol. Morphol. 2020, 53, 141-148. [CrossRef] [PubMed]

20. Ding, L.; Liang, X.-G.; Lou, Y.-J. Time-dependence of cardiomyocyte differentiation disturbed by peroxisome proliferator-activated receptor $\alpha$ inhibitor GW6471 in murine embryonic stem cells in vitro. Acta Pharmacol. Sin. 2007, 28, 634-642. [CrossRef]

21. Goto, T.; Lee, J.-Y.; Teraminami, A.; Kim, Y.-I.; Hirai, S.; Uemura, T.; Inoue, H.; Takahashi, N.; Kawada, T. Activation of peroxisome proliferator-activated receptor-alpha stimulates both differentiation and fatty acid oxidation in adipocytes. J. Lipid Res. 2011, 52, 873-884. [CrossRef] [PubMed]

22. Benameur, T.; Tual-Chalot, S.; Andriantsitohaina, R.; Martínez, M.C. PPAR $\alpha$ Is Essential for Microparticle-Induced Differentiation of Mouse Bone Marrow-Derived Endothelial Progenitor Cells and Angiogenesis. PLoS ONE 2010, 5, e12392. [CrossRef]

23. Sharifpanah, F.; Wartenberg, M.; Hannig, M.; Piper, H.-M.; Sauer, H. Peroxisome Proliferator-Activated Receptor $\alpha$ Agonists Enhance Cardiomyogenesis of Mouse ES Cells by Utilization of a Reactive Oxygen Species-Dependent Mechanism. Stem Cells 2008, 26, 64-71. [CrossRef]

24. Vergori, L.; Lauret, E.; Gaceb, A.; Beauvillain, C.; Andriantsitohaina, R.; Martinez, M.C. PPAR $\alpha$ Regulates Endothelial Progenitor Cell Maturation and Myeloid Lineage Differentiation Through a NADPH Oxidase-Dependent Mechanism in Mice. Stem Cells 2015, 33, 1292-1303. [CrossRef]

25. Gong, K.; Qu, B.; Wang, C.; Zhou, J.; Liao, D.; Zheng, W.; Pan, X. Peroxisome Proliferator-Activated Receptor $\alpha$ Facilitates Osteogenic Differentiation in MC3T3-E1 Cells via the Sirtuin 1-Dependent Signaling Pathway. Mol. Cells 2017, 40, 393-400. [CrossRef] [PubMed]

26. Kömüves, L.G.; Hanley, K.; Lefebvre, A.-M.; Man, M.-Q.; Ng, D.C.; Bikle, D.D.; Williams, M.L.; Elias, P.M.; Auwerx, J.; Feingold, K.R. Stimulation of PPAR $\alpha$ Promotes Epidermal Keratinocyte Differentiation In Vivo. J. Investig. Dermatol. 2000, 115, 353-360. [CrossRef] [PubMed]

27. Barker, N. Adult intestinal stem cells: Critical drivers of epithelial homeostasis and regeneration. Nat. Rev. Mol. Cell Biol. 2014, 15, 19-33. [CrossRef]

28. Huin, C.; Corriveau, L.; Bianchi, A.; Keller, J.M.; Collet, P.; Krémarik-Bouillaud, P.; Domenjoud, L.; Bécuwe, P.; Schohn, H.; Ménard, D.; et al. Differential Expression of Peroxisome Proliferator-activated Receptors (PPARs) in the Developing Human Fetal Digestive Tract. J. Histochem. Cytochem. 2000, 48, 603-611. [CrossRef] [PubMed]

29. Cizkova, K.; Rajdova, A.; Ehrmann, J. Spatio-Temporal Expression of Peroxisome Proliferator-Activated Receptor $\alpha$ During Human Prenatal Development. Basic Clin. Pharmacol. Toxicol. 2015, 116, 361-366. [CrossRef]

30. Bünger, M.; Bosch, H.M.; Van Der Meijde, J.; Kersten, S.; Hooiveld, G.J.; Muller, M. Genome-wide analysis of PPAR $\alpha$ activation in murine small intestine. Physiol. Genom. 2007, 30, 192-204. [CrossRef]

31. Yaghoubizadeh, M.; Pishkar, L.; Basati, G. Aberrant Expression of Peroxisome Proliferator-Activated Receptors in Colorectal Cancer and Their Association with Cancer Progression and Prognosis. Gastrointest. Tumors 2020, 7, 11-20. [CrossRef]

32. Huin, C.; Schohn, H.; Hatier, R.; Bentejac, M.; Antunes, L.; Plénat, F.; Bugaut, M.; Dauça, M. Expression of peroxisome proliferator-activated receptors alpha and gamma in differentiating human colon carcinoma Caco-2 cells. Biol. Cell 2002, 94, 15-27. [CrossRef]

33. Bourgine, J.; Billaut-Laden, I.; Happillon, M.; Lo-Guidice, J.-M.; Maunoury, V.; Imbenotte, M.; Broly, F. Gene Expression Profiling of Systems Involved in the Metabolism and the Disposition of Xenobiotics: Comparison between Human Intestinal Biopsy Samples and Colon Cell Lines. Drug Metab. Dispos. 2012, 40, 694-705. [CrossRef] [PubMed]

34. Cizkova, K.; Birke, P.; Malohlava, J.; Tauber, Z.; Huskova, Z.; Ehrmann, J. HT-29 and Caco2 Cell Lines Are Suitable Models for Studying the Role of Arachidonic Acid-Metabolizing Enzymes in Intestinal Cell Differentiation. Cells Tissues Organs 2019, 208, 37-47. [CrossRef] [PubMed]

35. Umemoto, T.; Fujiki, Y. Ligand-dependent nucleo-cytoplasmic shuttling of peroxisome proliferator-activated receptors, PPAR $\alpha$ and PPAR $\gamma$. Genes Cells 2012, 17, 576-596. [CrossRef]

36. Yamasaki, D.; Kawabe, N.; Nakamura, H.; Tachibana, K.; Ishimoto, K.; Tanaka, T.; Aburatani, H.; Sakai, J.; Hamakubo, T.; Kodama, T.; et al. Fenofibrate suppresses growth of the human hepatocellular carcinoma cell via PPAR $\alpha$-independent mechanisms. Eur. J. Cell Biol. 2011, 90, 657-664. [CrossRef]

37. Chen, L.; Peng, J.; Wang, Y.; Jiang, H.; Wang, W.; Dai, J.; Tang, M.; Wei, Y.; Kuang, H.; Xu, G.; et al. Fenofibrate-induced mitochondrial dysfunction and metabolic reprogramming reversal: The anti-tumor effects in gastric carcinoma cells mediated by the PPAR pathway. Am. J. Transl. Res. 2020, 12, 428-446.

38. Majeed, Y.; Upadhyay, R.; Alhousseiny, S.; Taha, T.; Musthak, A.; Shaheen, Y.; Jameel, M.; Triggle, C.R.; Ding, H. Potent and PPAR $\alpha$-independent anti-proliferative action of the hypolipidemic drug fenofibrate in VEGF-dependent angiosarcomas in vitro. Sci. Rep. 2019, 9, 6316. [CrossRef] 
39. Jan, C.-I.; Tsai, M.-H.; Chiu, C.-F.; Huang, Y.-P.; Liu, C.J.; Chang, N.W. Fenofibrate Suppresses Oral Tumorigenesis via Reprogramming Metabolic Processes: Potential Drug Repurposing for Oral Cancer. Int. J. Biol. Sci. 2016, 12, 786-798. [CrossRef]

40. Binello, E.; Mormone, E.; Emdad, L.; Kothari, H.; Germano, I.M. Characterization of fenofibrate-mediated anti-proliferative pro-apoptotic effects on high-grade gliomas and anti-invasive effects on glioma stem cells. J. Neuro-Oncol. 2014, 117, 225-234. [CrossRef]

41. Jiao, H. Cytotoxic Effect of Peroxisome Proliferator Fenofibrate on Human HepG2 Hepatoma Cell Line and Relevant Mechanisms. Toxicol. Appl. Pharmacol. 2002, 185, 172-179. [CrossRef]

42. Holland, C.M.; Saidi, S.A.; Evans, A.L.; Sharkey, A.M.; Latimer, J.A.; Crawford, R.A.; Charnock-Jones, D.S.; Print, C.G.; Smith, S.K. Transcriptome analysis of endometrial cancer identifies peroxisome proliferator-activated receptors as potential thera-peutic targets. Mol. Cancer Ther. 2004, 3, 993-1001.

43. Schmeel, L.C.; Schmeel, F.C.; Schmidt-Wolf, I.G.H. In Vitro Apoptosis Induction by Fenofibrate in Lymphoma and Multiple Myeloma. Anticancer. Res. 2017, 37, 3513-3520. [CrossRef]

44. Hwang, Y.P.; Won, S.S.; Jin, S.W.; Lee, G.H.; Pham, T.H.; Choi, J.H.; Kang, K.W.; Jeong, H.G. WY-14643 Regulates CYP1B1 Expression through Peroxisome Proliferator-Activated Receptor $\alpha$-Mediated Signaling in Human Breast Cancer Cells. Int. J. Mol. Sci. 2019, 20, 5928. [CrossRef] [PubMed]

45. Hashimoto, F.; Morita, M.; Iwasaki, K.; Takeda, S.; Hayashi, H. Effects of WY-14643 on peroxisomal enzyme activity and hormone secretion in immortalized human trophoblast cells. Biol. Pharm. Bull. 2009, 32, 1278-1282. [CrossRef] [PubMed]

46. Florio, R.; De Lellis, L.; DI Giacomo, V.; di Marcantonio, M.C.; Cristiano, L.; Basile, M.; Verginelli, F.; Verzilli, D.; Ammazzalorso, A.; Prasad, S.C.; et al. Effects of PPAR $\alpha$ inhibition in head and neck paraganglioma cells. PLoS ONE 2017, 12, e0178995. [CrossRef] [PubMed]

47. Abu Aboud, O.; Wettersten, H.I.; Weiss, R.H. Inhibition of PPAR $\alpha$ Induces Cell Cycle Arrest and Apoptosis, and Synergizes with Glycolysis Inhibition in Kidney Cancer Cells. PLoS ONE 2013, 8, e71115. [CrossRef]

48. Castelli, V.; Catanesi, M.; Alfonsetti, M.; Laezza, C.; Lombardi, F.; Cinque, B.; Cifone, M.G.; Ippoliti, R.; Benedetti, E.; Cimini, A.; et al. PPAR $\alpha$-Selective Antagonist GW6471 Inhibits Cell Growth in Breast Cancer Stem Cells Inducing Energy Imbalance and Metabolic Stress. Biomedicines 2021, 9, 127. [CrossRef]

49. Kumar, N.; Zhao, P.; Tomar, A.; Galea, C.A.; Khurana, S. Association of Villin with Phosphatidylinositol 4,5-Bisphosphate Regulates the Actin Cytoskeleton. J. Biol. Chem. 2004, 279, 3096-3110. [CrossRef]

50. Khurana, S.; George, S.P. Regulation of cell structure and function by actin-binding proteins: Villin's perspective. FEBS Lett. 2008, 582, 2128-2139. [CrossRef]

51. Wang, Q.; Zhou, Y.; Wang, X.; Chung, D.H.; Evers, B.M. Regulation of PTEN Expression in Intestinal Epithelial Cells by c-Jun NH2-Terminal Kinase Activation and Nuclear Factor-kB Inhibition. Cancer Res. 2007, 67, 7773-7781. [CrossRef]

52. De Araujo, W.; Vidal, F.C.B.; Souza, W.; Junior, J.C.D.F.; De Souza, W.; Morgado-Diaz, J.A. PI3K/Akt and GSK-3ß prevents in a differential fashion the malignant phenotype of colorectal cancer cells. J. Cancer Res. Clin. Oncol. 2010, 136, 1773-1782. [CrossRef]

53. Laprise, P.; Chailler, P.; Houde, M.; Beaulieu, J.-F.; Boucher, M.-J.; Rivard, N. Phosphatidylinositol 3-Kinase Controls Human Intestinal Epithelial Cell Differentiation by Promoting Adherens Junction Assembly and p38 MAPK Activation. J. Biol. Chem. 2001, 277, 8226-8234. [CrossRef]

54. Houde, M.; Laprise, P.; Jean, D.; Blais, M.; Asselin, C.; Rivard, N. Intestinal Epithelial Cell Differentiation Involves Activation of p38 Mitogen-activated Protein Kinase That Regulates the Homeobox Transcription Factor CDX2. J. Biol. Chem. 2001, 276, 21885-21894. [CrossRef]

55. Banfi, C.; Auwerx, J.; Poma, F.; Tremoli, E.; Mussoni, L. Induction of plasminogen activator inhibitor 1 by the PPAR $\alpha$ ligand, Wy-14,643, is dependent on ERK1/2 signaling pathway. Thromb. Haemost. 2003, 90, 611-619. [CrossRef] [PubMed]

56. Pauley, C.J.; Ledwith, B.J.; Kaplanski, C. Peroxisome proliferators activate growth regulatory pathways largely via peroxisome proliferator-activated receptor $\alpha$-independent mechanisms. Cell. Signal. 2002, 14, 351-358. [CrossRef]

57. Neuhaus, W.; Krämer, T.; Neuhoff, A.; Gölz, C.; Thal, S.C.; Förster, C.Y. Multifaceted Mechanisms of WY-14643 to Stabilize the Blood-Brain Barrier in a Model of Traumatic Brain Injury. Front. Mol. Neurosci. 2017, 10, 149. [CrossRef] [PubMed]

58. Leschelle, X.; Delpal, S.; Goubern, M.; Blottière, H.M.; Blachier, F. Butyrate metabolism upstream and downstream acetylCoA synthesis and growth control of human colon carcinoma cells. JBIC J. Biol. Inorg. Chem. 2000, 267, 6435-6442. [CrossRef]

59. Tylichová, Z.; Slavík, J.; Ciganek, M.; Ovesná, P.; Krčmář, P.; Strakova, N.; Machala, M.; Kozubík, A.; Hofmanová, J.; Vondráček, J. Butyrate and docosahexaenoic acid interact in alterations of specific lipid classes in differentiating colon cancer cells. J. Cell. Biochem. 2018, 119, 4664-4679. [CrossRef] [PubMed]

60. Yue, S.; Li, J.; Lee, S.-Y.; Lee, H.J.; Shao, T.; Song, B.; Cheng, L.; Masterson, T.A.; Liu, X.; Ratliff, T.L.; et al. Cholesteryl Ester Accumulation Induced by PTEN Loss and PI3K/AKT Activation Underlies Human Prostate Cancer Aggressiveness. Cell Metab. 2014, 19, 393-406. [CrossRef] [PubMed]

61. De Gonzalo-Calvo, D.; López-Vilaró, L.; Nasarre, L.; Perez-Olabarria, M.; Vázquez, T.; Escuin, D.; Badimon, L.; Barnadas, A.; Lerma, E.; Llorente-Cortés, V. Intratumor cholesteryl ester accumulation is associated with human breast cancer proliferation and aggressive potential: A molecular and clinicopathological study. BMC Cancer 2015, 15, 460. [CrossRef] [PubMed]

62. Abramczyk, H.; Surmacki, J.; Kopeć, M.; Olejnik, A.K.; Lubecka, K.; Fabianowska-Majewska, K. The role of lipid droplets and adipocytes in cancer. Raman imaging of cell cultures: MCF10A, MCF7, and MDA-MB-231 compared to adipocytes in cancerous human breast tissue. Analyst 2015, 140, 2224-2235. [CrossRef] 
63. Cotte, A.K.; Aires, V.; Fredon, M.; Limagne, E.; Derangère, V.; Thibaudin, M.; Humblin, E.; Scagliarini, A.; De Barros, J.P.; Hillon, P.; et al. Lysophosphatidylcholine acyltransferase 2-mediated lipid droplet production supports colorectal cancer chemoresistance. Nat. Commun. 2018, 9, 322. [CrossRef]

64. Cruz, A.L.S.; Barreto, E.D.A.; Fazolini, N.P.B.; Viola, J.P.B.; Bozza, P.T. Lipid droplets: Platforms with multiple functions in cancer hallmarks. Cell Death Dis. 2020, 11, 1-16. [CrossRef]

65. Qi, W.; Fitchev, P.S.; Cornwell, M.L.; Greenberg, J.; Cabe, M.; Weber, C.R.; Roy, H.K.; Crawford, S.E.; Savkovic, S.D. FOXO3 Growth Inhibition of Colonic Cells Is Dependent on Intraepithelial Lipid Droplet Density. J. Biol. Chem. 2013, 288, 16274-16281. [CrossRef]

66. Chen, W.-L.; Chen, Y.-L.; Chiang, Y.-M.; Wang, S.-G.; Lee, H.-M. Fenofibrate lowers lipid accumulation in myotubes by modulating the PPAR $\alpha /$ AMPK/FoxO1/ATGL pathway. Biochem. Pharmacol. 2012, 84, 522-531. [CrossRef]

67. Yan, F.; Wang, Q.; Xu, C.; Cao, M.; Zhou, X.; Wang, T.; Yu, C.; Jing, F.; Chen, W.; Gao, L.; et al. Peroxisome Proliferator-Activated Receptor $\alpha$ Activation Induces Hepatic Steatosis, Suggesting an Adverse Effect. PLoS ONE 2014, 9, e99245. [CrossRef]

68. Chang, N.-W.; Wu, C.-T.; Chen, D.-R.; Yeh, C.-Y.; Lin, C. High levels of arachidonic acid and peroxisome proliferator-activated receptor-alpha in breast cancer tissues are associated with promoting cancer cell proliferation. J. Nutr. Biochem. 2013, 24, 274-281. [CrossRef] [PubMed]

69. Zuo, N.; Zheng, X.; Liu, H.; Ma, X. Fenofibrate, a PPAR $\alpha$ agonist, protect proximal tubular cells from albumin-bound fatty acids induced apoptosis via the activation of NF-kB. Int. J. Clin. Exp. Pathol. 2015, 8, 10653-10661.

70. Sung, H.; Ferlay, J.; Siegel, R.L.; Laversanne, M.; Soerjomataram, I.; Jemal, A.; Bray, F. Global Cancer Statistics 2020: Globocan Estimates of Incidence and Mortality Worldwide for 36 Cancers in 185 Countries. CA A Cancer J. Clin. 2021, 71, 209-249. [CrossRef] [PubMed]

71. Luo, Y.; Xie, C.; Brocker, C.N.; Fan, J.; Wu, X.; Feng, L.; Wang, Q.; Zhao, J.; Lu, D.; Tandon, M.; et al. Intestinal PPAR $\alpha$ Protects Against Colon Carcinogenesis via Regulation of Methyltransferases DNMT1 and PRMT6. Gastroenterology 2019, 157, 744-759.e4. [CrossRef] [PubMed] 